\title{
Some Trace Elements Investigation in Ground Water of Bhopal \& Sehore District in Madhya Pradesh: India
}

\author{
${ }^{1}$ AKHILESH JINWAL; ${ }^{2}$ SAVITA DIXIT; ${ }^{3}$ SUMAN MALIK \\ ${ }^{1}$ Research Assistant, Water Quality Laboratory Level II+ WRD Bhopal Mob 09827255572 email: jinwalakhilesh@rediffmail.com. \\ ${ }^{2}$ Applied Chemistry Department Maulana Azad National Institute of Technology Bhopal M.P. India in No. 462007, Phone 9107552428155 \\ emailsavitadixit1@yahoo.com \\ ${ }^{3}$ Chemistry Department, Sadhu Vaswani College, Saint Hirdaram Nagar, Bairagarh Bhopal M.P.
}

\begin{abstract}
This paper deals with short review and the determination of seven heavy metals viz: $\mathrm{Cu}, \mathrm{Fe}, \mathrm{Mn}$, $\mathrm{Zn}, \mathrm{Ni}, \mathrm{Cr}$ and $\mathrm{Pb}$ in the groundwater of different sites of two districts (Sehore and Bhopal) of Madhya Pradesh. All activities carried out on the ground surface have direct or indirect impact on the groundwater whether associated with urban, industrial or agricultural activities large scale concentrated source of pollutants such as industrial discharge, and subsurface injection of chemicals and hazardous are obvious source of ground water pollutants . This study was carried out in the month of during February to April 2003. The samples were collected from eight different source of Sehore district and seven different source of Bhopal city. The results obtained are compared with safe limits in PPM for heavy metals laid down by BIS, WHO, ICMR, APHA.@ JASEM
\end{abstract}

Water is one of the very precious substances on the earth. It is very essential for the existence and survival of life. As population grows and their need for water increases, the pressure on our groundwater resources also increases. In many areas of the world, groundwater is now being over extracted, in some places massively so, the results is falling water levels and declining well yield, land subsidence and ecological damage such as the drying out of wetlands. The trace metals in water behave in a typical manner. No single mechanism is sufficient to explain the process that are undergoing in the water. Trace metals like $\mathrm{Fe}, \mathrm{Mn}, \mathrm{Cu}, \mathrm{Zn}, \mathrm{Co}$, Ni etc are very important for the proper functioning of the biological system and their deficiency or excess in the human system can lead number of disorders other trace metals like $\mathrm{Pb}, \mathrm{As}, \mathrm{Hg}$ etc are not only biologically non essential but definitely toxic. The potential toxic metal element such as $\mathrm{Cr}, \mathrm{Pb}, \mathrm{Cu}, \mathrm{Zn}$ etc are identified to cause health hazards in animals. In case of many heavy metals, bio-magnification occurs through food chain so, it is necessary to discuss the theoretical aspects of trace metals for easy understanding of their metabolic activities.

$\mathrm{Cu}$ and $\mathrm{Fe}$ is mixed in groundwater by rocks bearing iron and copper bearing ores viz; cuprite, melakite, azurites, hematite, magnetite and iron pyrite. $\mathrm{Fe}$ in surface water is generally present in the ferric (Fe III) state. Concentration of Fe greater than $1 \mathrm{mg} /$ lit. have been reported to occur in groundwater. The average daily requirements of iron is considered to be $10 \mathrm{mg}$. Mn plays a role in the proper functioning of flavoroteins and in the synthesis of sulphated mucopolysaccaharides, cholesterol, hemoglobin and in many other metabolic processes.

Leaching of zinc from galvanized pipes, brass and zinc containing fittings plays a serious role in groundwater pollution, but in required quantity it is very essential for human metabolism. Dye and tannery industries pollute the water through chromium and other harmful chemicals. Many nickel salts are water soluble there contamination can arise. The level of nickel usually found in food and water are not considered a serious health hazards. Because of low solubility of chromium the levels found in water are usually low $(9.7 \mathrm{mg} / \mathrm{lit})$. Lead comes in water by corrosion in lead alloys made pipes and with out treating car and motors batteries. Many industries prepared litharge and lead peroxide pollute the groundwater by their effluents. The levels in drinking water however can be much higher owing to the use of lead services pipes and lead lined storage tanks. Moreover the domestic sewage and sewage of many chemicals laboratories play an important role in pollution of groundwater. They discharge detergents, chemically treated wastewater and spoilt vegetables, fruits and used chemicals.

Trace elements in groundwater: Pollution of groundwater is an impairment of water quality by chemicals, heat or bacteria to a degree, that does not necessarily create and actual public heath hazards, but does adversely affect such water for domestic, farm, municipal or industrial use. Many trace elements are essential nutrients however certain trace elements such as $\mathrm{As}, \mathrm{Cd}$, and $\mathrm{Hg}$ are known to be persistent environment contamination and toxic to most form of life. Trace elements are generally present in small concentration in natural water system. Their occurrence in groundwater and surface water can be due to natural sources such as dissolution of naturally occurring minerals containing trace elements in the soil zone or the aquifer material or to human activities such as mining, fuels, smelting of ores and improper disposal of industrial wastes. 


\section{MATERIAL AND METHODS}

Selection of sites: Seven water samples were collected from Bhopal district and eight water samples were collected from Sehore district from different sites in polyethylene container which were thoroughly cleaned with 1:1 HNO3 rinsed several times with distilled water and dried in electric oven. The collected water samples were grouped under categories S1, S2, S3, S4, S5, S6, S7, (Bhopal District) and S8, S9, S10, S11, S12, S13, S14, S15 (Sehore District).

Bhopal District
S1 Najirabad
S2 Berasia
S3 Gunga
S4 Islamnagar
S5 Balrampurghati
S6 Bilkhiriya
S7 Ahmedpur

Sehore District
S8 Astha
S9 Jattakheda
S10 Chandbad
S11 Sehore
S12 Bilkisganj
S13 Icchawar
S14 Nadan
S15 Larkui

Reagents: Only analytical reagent grade chemical were used.

Analytical Procedure: Flame Atomic Absorption spectrophotometer methods were used for the determination of all the trace metals resonance lines and hollow cathode lamps of respective metals were used and the instruments was optimize for maximum response. Air and Acetylene were used as oxidant and fuel respectively.

\section{RESULTS AND DISCUSSION}

The distribution of some trace metals in Bhopal and Sehore districts dug wells water samples have been depicted in table 1 and 2 respectively. Safe limits in PPM ( as per BIS,WHO, ICMR, APHA ) and minimum acceptable and maximum acceptable limits for drinking purpose use of groundwater and adverse effect on living bodies are show in table 3 .

Table 1: Concentration of heavy metals in Bhopal District.

\begin{tabular}{llllllll}
\hline Heavy & \multicolumn{7}{c}{ Concentration in PPB } \\
\cline { 2 - 8 } & $\mathrm{S} 1$ & $\mathrm{~S} 2$ & $\mathrm{~S} 3$ & $\mathrm{~S} 4$ & $\mathrm{~S} 5$ & $\mathrm{~S} 6$ & $\mathrm{~S} 7$ \\
$\mathrm{Cu}$ & 7 & 7 & 3 & 2 & 0 & 6 & 0 \\
$\mathrm{Fe}$ & 330 & 913 & 145 & 1037 & 509 & 134 & 0 \\
$\mathrm{Mn}$ & 38 & 58 & 1 & 1 & 60 & 50 & 0 \\
$\mathrm{Zn}$ & 232 & 30 & 338 & 794 & 0 & 41 & 1 \\
$\mathrm{Ni}$ & 14 & 0 & 0 & 0 & 30 & 9 & 0 \\
$\mathrm{Cr}$ & 46 & 33 & 0 & 69 & 27 & 60 & 121 \\
\hline $\mathrm{Pb}$ & 37 & 0 & 0 & 0 & 0 & 0 & 29 \\
\hline
\end{tabular}

Table 2: Concentration of heavy metals in Sehore District.

\begin{tabular}{lllllllll}
\hline Heavy & \multicolumn{7}{c}{ Concentration in PPB } \\
\cline { 2 - 9 } & $\mathrm{S} 8$ & $\mathrm{~S} 9$ & $\mathrm{~S} 10$ & $\mathrm{~S} 11$ & $\mathrm{~S} 12$ & $\mathrm{~S} 13$ & $\mathrm{~S} 14$ & $\mathrm{~S} 15$ \\
$\mathrm{Cu}$ & 4 & 0 & 0 & 0 & 17 & 4 & 3 & 16 \\
$\mathrm{Fe}$ & 0 & 7 & 459 & 0 & 3330 & 0 & 7 & 263 \\
$\mathrm{Mn}$ & 121 & 0 & 35 & 11 & 67 & 0 & 20 & 26 \\
$\mathrm{Zn}$ & 346 & 91 & 79 & 121 & 86 & 83 & 998 & 601 \\
$\mathrm{Ni}$ & 16 & 4 & 0 & 0 & 0 & 0 & 0 & 32 \\
$\mathrm{Cr}$ & 0 & 27 & 0 & 0 & 17 & 0 & 21 & 0 \\
\hline $\mathrm{Pb}$ & 0 & 0 & 50 & 60 & 0 & 0 & 26 & 0 \\
\hline
\end{tabular}

Table 3: Safe limits in PPM (as per BIS, WHO, ICMR, APHA) \& Minimum Acceptable \& Maximum Acceptable limits for drinking purpose use of Ground Water \& Adverse effect on wring Bodies.

\begin{tabular}{|c|c|c|c|c|}
\hline S/No. & Heavy Metals & \multicolumn{2}{|c|}{ Ground Water } & \multirow[t]{2}{*}{ Effect on lifting } \\
\hline & & Maxi & Mini & \\
\hline 1 & Lead & 0.05 & & $\begin{array}{l}\text { Toxic plumb solvency diseases, burning in mouth, several inflammations in gastro } \\
\text { intestinal track, causes paralysis mental confusion, visual disturbance anemia etc. }\end{array}$ \\
\hline 2 & Chromium & 0.05 & & $\begin{array}{l}\text { Carcinogenic acuity (cancer), can produce coetaneous and nasal mucous membrane } \\
\text { ulcer \& Dermatitis, Hexavalent Cr causes lung tumors }\end{array}$ \\
\hline 3 & Copper & 1.5 & 0.05 & $\begin{array}{l}\text { Astringent taste but essential elements for metabolism, deficiency results is anemia in } \\
\text { infants, excess may results in liver damage. }\end{array}$ \\
\hline 4 & Nickel & 0.02 & & May be carcinogenic, can react with DNA. Resulting in DNA damage. \\
\hline 5 & Mercury & 0.001 & & $\begin{array}{l}\text { Causes minimata disease also causes blue baby disease in Infants the color of skin in } \\
\text { baby is turn into blue. Paralysis. }\end{array}$ \\
\hline 6 & Iron & 0.3 & 1.0 & Promote Iron Bacteria in water, bad Taste, In trace is nutritional. \\
\hline 7 & Manganese & 0.5 & 0.05 & $\begin{array}{l}\text { Produces bad taste, essential as cofactor in enzyme system \& metabolism process. } \\
\text { Excess causes reduced metabolism of iron to form Hemoglobin. }\end{array}$ \\
\hline 8 & Zinc & 15 & 5 & $\begin{array}{l}\text { Causes Astringent taste \& opalescence in water, Essential elements in human } \\
\text { metabolism. }\end{array}$ \\
\hline 9 & Selenium & 0.01 & & $\begin{array}{l}\text { Toxic, leads to hair \& finger loss, numbness in fingers or toes, causes circulatory } \\
\text { problems. }\end{array}$ \\
\hline 10 & Arsenic & 0.05 & & $\begin{array}{l}\text { Beyond this limit water become toxic, causes skin damage circulatory problem } \\
\text { increase risk of skin cancer, (found in ground water in Rajnandgaon district in M.P. } \\
\text { also seen very much skin problems in slums area that are mainly depends on ground } \\
\text { water source for drinking purpose.) }\end{array}$ \\
\hline
\end{tabular}

$1 \mathrm{PPM}=1000 \mathrm{PPB}$

* Corresponding author: Akhilesh Jinwal 
Discussion of Results: The occurrence of trace elements in natural water is affected both by hydro chemical factors like mineral composition of the rocks, soil characteristics etc as well as by anthropogenic activities and likely to show both temporal and spatial variation.

Copper: According to limits prescribed by various authorities (WHO, ICMR, APHA, BIS) it was found that all the samples collected from the sources were free from copper, the average value of copper in all water samples are much below the permissible limits. Iron: According to BIS and ICMR the maximum allowable concentration and the permissible concentration in drinking water in $1.0 \mathrm{PPM}$ and 0.3 PPM respectively. It is content of hemoglobin, so it is very necessary for all living organism but in excess promote iron bacteria in water. Iron is excess in S1, S2, S4, S5 samples of Bhopal district and S10, S12 samples of Sehore district.

Manganese: The maximum allowable concentration and permissible concentration of manganese in drinking water is 0.5 PPM and 0.05 PPM respectively according to WHO, BIS, and ICMR. Most of the water samples analyses had less than 100 PPB (0.1 PPM) except S8 sample in Sehore district.

Zinc: Zinc is an essential plant and human nutrient. The maximum allowable concentration and permissible concentration of zinc in drinking water are 15 PPM and 5 PPM respectively. According to WHO, ICMR, APHA the average value of zinc in all the water samples are below the permissible limit. The concentration of zinc in all water samples is below 1000 PPB (1 PPM). Hence all the samples collected from all sources are below from maximum permissible limit for zinc.

Nickel: The permissible concentration of nickel in groundwater is 0.02 PPM. Only S5 in Bhopal and S15 sample in Sehore are out of limit. Remaining samples are with in the permissible limit.

Chromium: The maximum permissible limit of chromium in drinking water according to $\mathrm{WHO}$ and ICMR is 0.05 PPM. Small amount of chromium is essential to mammals but in excess it produces harmful effects. The obtained data shows that chromium content in water is with in limits prescribed by the various authorities except slightly higher in S4, S6, S7 in Bhopal district.

Lead: It is very toxic element, which accumulates in the skeletal structure of man and animal. The maximum permissible concentration of lead in drinking water is $0.05 \mathrm{PPM}$. According to $\mathrm{WHO}$ and ICMR almost all the water samples had less than 50 PPB of lead. Only S11 Sample in Sehore district is slightly higher than maximum permissible limit.
Conclusion: Systematic study of the chemical data obtained as results of analysis of ground water samples from Sehore and Bhopal districts are affected by one or more of the studied trace metals. At least $60 \%$ of the population is still dependent on ground water sources for drinking purpose, especially in outer city and distant villages. According to the analysis of some water samples of Bhopal and Sehore district of Madhya Pradesh, the Copper, Manganese, Lead, and Zinc are not found beyond limit, while Iron and Chromium are found towards little higher sides on some places and Nickel is found higher only in Balrampurghati and Larkui sample, but these metals are essentials for our body metabolism. They play role of co-factor in activity of enzyme.

Thus to keep ground water free from $\mathrm{Cr}, \mathrm{Fe}, \mathrm{Mn}, \mathrm{Pb}$, etc and other ions the following Recommendation should be taken into account.

1. Chromium enriched refuge should be properly treated and then disposed off. Construction of ground water structure on dumping sites or its immediate vicinity should be avoided as $\mathrm{Cr}$ pollution relates to point source.

2. Industries should be set up their effluents treatment plants (EFT) independent or jointly as per norms and should remain effectively operational in order to safe guard the ground water for future generation.

3. In agricultural excessive use of nitrogenous and phosphates fertilizers should be avoided so that it does not leach down to ground water and deteriorate its quality.

4. Mass awareness should be generated about the over use of pesticide, its harmful effects on quality of water and human health.

\section{REFERENCES}

Nigam Neelam, Mehrotra Pooja, Ground water pollution in U.P. "Groundwater 2007" National Seminar, Bhopal, Vol. II, pp 239-242.

Standard of water for drinking and other purposes, BIS Publications, New Delhi 1983.

Mohapatra U.K., Singh B.C., Trace metal in drinking water from different sources in the old city of Cuttack. Indian Jour. of Environ. Health, 41(2) 115-120, (1999).

E.J. Underwood, Trace element in human and animal nutrition. Third edition, Academic Press, New York 1971.

H.J. M. Bowen, The Biochemistry of Trace element, Proceedings of symposium, IEAA, Vienna, pp 393, 1972. 
D. Satyanarayana, Shastri M.N., Science reporter 20 (4) 1983.

Bryan, G.W., 1976 Heavy metals contamination in the sea: R Johnston (ed) Marine Publication, Academic Press, London.

Lowe, W. 1970, Origin and Characteristic of Toxic wastes, with particular reference to the metal industries: Water pollution control, 69:270-273.

Sitakumar, Subbaiah, K.V. Sai Gopal, D.V.R. 2001 "Studies of certain trace element in industries effluent sediments and their effect on plant physiology, Pollution Research, 20 (1): 99-102.

Sudhira H.S., Kumar V.S., 2000 Monitoring of lake water quality in Mysore city, Proceeding of lake 2000: International Symposium on restoration of lakes and wetlands, 27-29 Nov. 2000, CSIC Auditorium, I I Sc, Bangalore: 1-10.

F.J. Dart, The hazard of Iron, Ottawa, Water and pollution control, Canada 1974.
National Research Council (Committee on Medical and Biological effects on Environmental pollutants) Manganese, Washington DC National academy of Sciences, 1973.

E. J. Underwood, Trace elements in human and animal nutrition, $\mathrm{IV}^{\text {th }}$ edition, New York Academic Press, pp 545, 1977.

National Research Council, Chromium, Washington DC, National Academy of Sciences, 1974.

National Research Council, Drinking Water and Health, Washington DC, National Academy of Sciences, 1977.

Walker, W. H.., 1969, Illinois groundwater pollution. Jour. Ame. Water Wks.Asso.61 (1) 31-40.

The Dark Zone, April 15 $5^{\text {th }}, 2003$ Down to Earth Page 38-45.

* Corresponding author: Akhilesh Jinwal 